\title{
When the shift hits the critical fan: A Foucauldian analysis
}

\author{
Heather Brunskell-Evans \\ School of Education \& Training
}

\section{Introduction}

In the past 15 years in the UK, the state has acquired powers, which mark a qualitative shift in its relationship to higher education. Since the introduction and implementation of the Further and Higher Education Act 1992, the Teaching and Higher Education Act 1998 and the Higher Education Act 2004, a whole raft of changes have occurred which include the following: Widening participation; the development of interdisciplinary, experiential and workplace-based learning focused on a theorypractice dialogue; quality assurance; and new funding models which encompass public and private partnerships. The transformation of higher education can be placed in the context of New Labour's overall strategies for overarching reform of public services, as set out in the Prime Minister's Strategy Unit's discussion paper The UK Government's Approach to Public Service Reform (2006).

An optimistic view of changes to higher education is that they simultaneously obey democratic and economic imperatives. There is an avowed commitment through the widening participation agenda to social inclusion and citizenship, and to providing the changing skills base necessary for the global economy. A more cynical view is that, when put under critical scrutiny, as well as being emancipatory, in some senses these changes can be seen to mobilise regulatory and disciplinary practices. This paper reflects on what kinds of teaching and learning are promoted by the new relationship between the state and the university. It argues that, whilst governmental directives for innovations and transformations in teaching and learning allegedly empower students and put their interests at the centre, reforms can also be seen to consist of supervisory and controlling mechanisms with regard both to our own practices as teachers and the knowledge/ learning we provide for the students.

\section{Higher education as the object of government control}

The Further and Higher Education Act 1992 marked a qualitative shift in the state's relationship with higher education. Writing in the immediate aftermath of the Act, Salter and Tapper (1994) point out that the accumulated powers of the state did not arrive 'out of the blue' in 1992, but emerged after the Second World War out of the ideological struggles between the economic view of higher education and the traditional, liberal ideal of the university as academically autonomous and as a site for critical thought. This conflict over the purpose and function of the university was played out over two political periods: that of the welfare state up to the 1970s and that of the Thatcher era.

Whereas the university had previously been understood as relatively autonomous, since 1992 it has been tied to the state across a whole range of issues, which ultimately involve its accountability to the needs of the economy. As such, unlike any other historical period, the state has effected change 
on a vast scale and in a manner that determines the everyday practices of the academy, including teaching and learning. In describing the powers of the state, Salter and Tapper (1994) problematise simplistic conceptions of the state and argue that it does not designate a single identity, but numerous and complex organisations and institutions that make up the state apparatus. The state does not have 'a single, homogenous identity in terms of either organisation or values' (1994, p. 19). The unifying ideology of the purpose of higher education is mobilised by numerous components of the state apparatus according to the 'ability of the dominant bureaucracy... to orchestrate the actions of its different parts' (1994, p. 19).

Olssen, Codd and O'Neill (2004) extend analysis of the powers of the state to include the last decade of the 20th century and the beginning of the 21st century, a period that witnessed the formulation and implementation of the Teaching and Higher Education Act 1998 and the Higher Education Act 2004. These theorists characterise the New Labour government as neo-liberal, and as such, rather than constituting a radical shift from the previous governmental administration, the current government extends the political project of the New Right. Olssen et al. (2004) take up the theoretical premise elaborated above, that the state exercises an unprecedented control over the contemporary university. However, they shift the debate onto a discussion that involves political motivation for control of the university beyond the requirements of the economic and onto the governmental need for social control per se.

They analyse this phenomenon through the conceptual tools made available by the philosopher/ social theorist Michel Foucault (1927-1984), in particular Foucault's concept of 'governmentality'. This, they argue, provides a powerful tool for understanding how higher education is tied to both politics and economics in Western liberal democratic societies, and how this is accomplished through the production of self-governing subjects who tailor their educational and life aspirations and desires to the requirements of the state.

\section{Foucault and governmentality: The liberal democratic state}

Foucault (1991) developed the neologism 'governmentality' to describe the structures of power in liberal democracies by which the conduct of individuals is orchestrated through mobilising their selforganising capacities so that individual subjects align their needs, aspirations, and hopes to the needs of the state. His aim was not to ascertain the legitimacy or illegitimacy of state power, but to understand the nature of governmental power in modern liberal democracies since the $19^{\text {th }}$ century as specific forms of state 'reason', linked to technologies that exercise collective power over individuals as 'free' subjects.

In earlier work Foucault argued social control in liberal democracy takes effect through the production of individual, subjective identity around an axis of normal/abnormalcy. To be governed in a liberal democracy is to be subjected, i.e. to be turned by the apparatuses of state (and the power and knowledge relations deployed) into a particular form of subject, who imagines her/himself to be free. Foucault's argument is that we are extremely normatively disciplined in every area of existence, including our thoughts, passions and desires. This condition of normalcy is reproduced through institutions such as schools, prisons and hospitals and feels to individual subjects as natural and inevitable. In Foucault's view, subjects are never 'free' in the sense in which we understand freedom in liberal democracy, namely that as subjects we exist as autonomous individuals prior to or anterior to 
the power which is exercised over us. The subject is brought into being through power relations, and the knowledges (psychology, sociology, anthropology, and economics) that are attached to them.

The later development of the concept of governmentality allowed Foucault to shift analysis from the micro-practices of education, the prison system and the health services that produce us as specific subjects, to the collective dimensions of governmental power as manifested by the modern, liberal, democratic state. As such, he provides a form of analysis that demonstrates the exercise of power within liberal democracies and allows us to see that educational and economic practices mutually condition and adapt to each other in ways that regularise and normalise individuals. This analysis is fruitful because it does not represent such processes, as in Marxist discourses, as the outcome of a necessary determination by the economic base, or describe the 'fit' between state power and the individual subject solely in terms of her/his oppression by a power imposed from 'above'.

Foucault argues that governmentality, since the growth of nascent, liberal democracies in the late 18th and 19th centuries, has involved the complex calculations, programmes, strategies, reflections and tactics by which government attempts to 'conduct the conduct' of individuals and groups of individuals in order to achieve certain ends. Increasingly, those ends are 'not just to control, subdue, discipline, normalise, or reform them, but also to make them more intelligent, wise, happy, virtuous, productive, docile, enterprising, fulfilled, self-esteeming, empowered or whatever' (Rose, 1988, p. 12).

Governmentality is not simply about control in its negative sense, but in its positive sense, in its contribution to the security and well-being of the population. Foucault poses the question of the how of liberal government - 'how to govern oneself, how to be governed, how to govern others, by whom the people will accept being governed'. Governmentality is not one homogenous or blanket mode of liberal democratic government, although it has the central, component elements described above, since it shifts according to historical and political circumstances. Olssen et al. (2004), argue that neo-liberalism is a reason of state that emerged in the 1980 s out of an ideological and economic reaction to the welfare state and its perceived deficiencies. As such it traverses the New Right and New Labour. In the neo-liberal view, the welfare state played too great a role in relation to economic management, restricting the operations of the market and creating unnecessary inefficiencies as a result of a 'top-heavy' and cumbersome bureaucracies. It also produced individuals who were difficult to govern, ranging from those who did not take individual responsibility and were welfare dependent, through to those who were rebellious and transgressive, such as students and academics.

The state has developed a new approach to managing the economy and to the ordering of population, through the following strategies: Reformation of public administration and reduction of the size and operations of the state; governing 'from a distance' through concepts of choice, freedom, empowerment, and autonomy; inducing individuals to take responsibility for themselves at the sites of the family, education, health provision, pensions and so on. This mode of governing can be exemplified by New Labour's approach to public service reform:

'Since 1997 the government has substantially increased investment in public services... But increased spending is not enough on its own to ensure improvements. Reform is needed to improve efficiency, quality of service and the fairness of provision. The UK government's current approach to public service reform combines pressure from government (top down and voice), competitive provision; and measures to build the capability and capacity of civil and public servants and central and local government.' (Prime Minister's Strategy Unit, 2006, p. 3). 
From a Foucauldian view, the 'empowerment' of citizens does not make individuals free from power, but induces individuals to turn themselves into the kinds of subjects necessary for government. Thus, rather than represent a withdrawal of state power, neo-liberal strategies of government deploy a power which is increasingly pervasive since it functions to simultaneously centralise and individualise. I explore below the inherent dangers of higher education being harnessed to the interests of neoliberal reason through the state's re-configuration of learners, the learning environment and teachers in higher education.

\section{Higher education: The politics of new modes of learning and the de-professionalisation of academics}

Widening participation is popularly understood as greater participation in, access to and equity in the liberal democratic political framework. The distinction made between education and training in European universities (in contrast to universities in the United States of America) is now beginning to disappear. A new model of higher education knowledge is emerging: employability skills-based training; new qualification frameworks with 'flexible pathways' and credit transfer which provide a 'seamlessness' between work and education; and a push for on-going improvement of outcomes as measured by student access, participation and retention, etc.

As a result of this new configuration of the university, knowledge is increasingly evaluated for its pragmatic, utilitarian value rather than as an end in itself. Competency-based approaches to curriculum delivery and learning are driven by strong, externally defined standards that treat learning as a set of discrete outcomes which are not multi-dimensional. Changes to knowledge are driven, in part, by the needs of trans-national companies and related knowledge-based industries: Partnerships between universities and industries are being formed and carefully nurtured; the boundaries between the academy, government and business have been loosened and re-formulated; and corporate interests play a more powerful role in determining the purpose of higher education.

Greater co-ordination and co-operation between public and private institutions has resulted in new funding models for higher education and, although it is still largely dependent on state funding, the university is expected to meet the requirements of the private sector economy. There are multiple linkages between the university and the different stakeholders in the economy and since universities are framed as a source of labour market training they are being increasingly encouraged to work with industry and commerce to generate knowledge, wealth and regional and national economies.

Olssen et al. (2004) agree and point out that in higher education, as in the workforce more generally, neo-liberal reason involves new forms of managing students and staff. With regard to students, notions such as 'flexibility' are integral to neo-liberal work and management relations, and require malleable individuals who continually train and re-train to meet the continuing changes of the economic process. The notion of "flexibility' redesigns skills and human capital as the personal responsibility of the individual worker, enabling the structures of both the economy and state maximum ability to accommodate change' (2004, p. 189). Power 'is concentrated, focused and implemented while not appearing to be centralised. In Foucauldian terms, flexibility represents a micro-technology of power that sustains relations of governmentality' (ibid). 
With regard to staff, neo-liberal governmental technologies comprise a new form of power which systematically undoes and reconstructs the practices of professionalism in higher education. Academic identity is no longer linked to one's academic discipline, but to league-table scores, quality assurance and managerialism. The irony is that whilst academics are increasingly expected to operate managerially (re-professionalisation), they are also expected to consent to being led (de-professionalisation). There are two salient features to de-professionalisation: The beginnings of removal of discretionary power with regard to pedagogy; constraints imposed on teaching practice by having to meet bureaucratic criteria imposed by quality assurance agencies such as the QAA. Whist the rationale for externality is that it enhances quality and professionalism, the fact remains that quality assurance is the authoritative construction of norms, with limited opportunities for individuals to question their legitimacy and move beyond conventionally justified beliefs and values. Academics no longer legislate for what is correct knowledge, 'they are more likely to be interpreters of the workplace or consultants to knowledge workers such as teachers, etc' (Morely, 2003, p. 92).

\section{Conclusion}

My own view is that in the UK, there is a culture of compliance to the policy discourses of higher education, which means that I am required, like countless colleagues, to perform within regulatory frameworks. The contractual basis upon which academics are employed is premised on a need for compliance, monitoring and accountability, organised through a new form of managerialism and established through measurable outputs. Does this broaden or narrow education? Without coming to a conclusion about this, I want to shift the terms of the debate. One can see that, within the university, there is an inter-locking of the 'tutor-subject' and 'student-subject' as a local enacting of policy discourse which shifts the purpose of learning onto a different terrain than that of critical thought, which was the dominant discourse of adult education throughout most of the 20th century. Critical thinking is usually characterised as the process of unearthing and then researching, the assumptions one is operating under, primarily by taking different perspectives on familiar, taken-forgranted beliefs and behaviours' (Brookfield, 2005: vii-viii). Critical thinking is thus an inherently political process, one that is becoming increasingly difficult to sustain in higher education, both in oneself and in one's students.

True freedom, in the Foucauldian view, can never exist outside of power but exists in our ability as subjects to comprehend how we have been 'put together' by discursive practices, namely systems of thought to which practices are attached, so that we can resist and challenge them. The real task of scholarly critique is thus to examine those aspects of educational institutions that appear to be both neutral and independent, and to do so in such a manner that the powers that are exercised obscurely are unmasked so that we are in a position to resist them if we so choose. The freedom to resist, unlike a traditional Marxist position, does not involve globalising visions of overthrowing power, since this would be impossible, but the analysis of the micro-politics of power and how these induce us to become particular kinds of tutor-subjects and student-subjects.

As a teacher of the theory and practice of education (within schools, and further and higher education), I am placed within the governmental changes to higher education which I have to operate and mobilise. However, I also attempt to maintain a critical distance to ensure that I am not incorporated into practices and ideologies that are in fundamental opposition to my own beliefs about the nature of scholarship and of best practice. In other words, in my 
teaching and in my research I take the 'new' modes of teaching and learning as an object of enquiry rather than an internalised modus operandi ${ }^{1}$

\section{References}

Barry, A. Osborne, T. and Rose, N. (eds.) (1996) Foucault and Political Reason. London: UCL Press. Brookfield, S.D. (2005) The Power of Critical Theory for Adult Learning and Teaching. Berkshire: OUP. Burchell, G. Gordon, C. and Miller, P. (eds.) (1991) The Foucault Effect: Studies in Governmentality. London: Harvester Wheatsheaf.

Fejes, A., and Nicoll, K. (eds.) (2008) Foucault and Lifelong Learning: Governing the Subject. London and New York: Routledge.

Foucault, M. (1991) 'Governmentality'. In Burchell, G. Gordon, C. and Miller, P. (eds.) The Foucault Effect: Studies in Governmentality. USA: University of Chicago Press.

Morley, L. (2003) Quality and Power in Higher Education. Berkshire: SRHE and OUP.

Olssen, M. Codd, J. and O'Neill, A. M. (2004) Education Policy: Globalisation, Citizenship and Democracy. London: Sage.

Prime Minister's Strategy Unit (2006) The UK Government's Approach to Public Service Reform. Online. Available at www.cabinetoffice.gov.uk/strategy/work_areas/public_service_reform.aspx Rose, N. (1998) Inventing Our Selves: Psychology, Power and Personhood. Cambridge: Cambridge University Press.

Rose, N. (1999) Powers of Freedom: Reframing Political Thought. Cambridge: Cambridge University Press.

Salter, B. and Tapper, T. (1994) The State and Higher Education. Essex: The Woburn Press.

\footnotetext{
${ }^{1}$ I am indebted to Louise Morley for drawing out similar distinctions between her own need as an academic manager and scholar for compliance with discourses of quality assurance and to take them as the object of her own, feminist theoretical enquiry. She describes her position in academia as one of 'hybridity' (2003: $x)$.
} 